\author{
Tamara Zacharuk \\ ORCID: 0000-0001-7306-5436 \\ Ewa Jówko \\ ORCID: 0000-0002-4687-6281 \\ Uniwersytet Przyrodniczo-Humanistyczny w Siedlcach \\ Wydział Nauk Społecznych
}

\title{
VII MIĘDZYNARODOWY KONGRES INKLUZJI SPOŁECZNEJ - SPRAWOZDANIE MERYTORYCZNE
}

\author{
Substantive Report of the 7th International Congress \\ of Social Inclusion
}

https://doi.org/10.34739/sn.2020.20.12

Uniwersytet Przyrodniczo-Humanistyczny w Siedlcach od 2014 r. jest organizatorem Międzynarodowego Kongresu Inkluzji Społecznej. Celem Kongresu jest skupienie wokół środowiska akademickiego Uniwersytetu naukowców, ekspertów i praktyków zajmujących się różnymi aspektami problematyki inkluzji społecznej - w tym edukacją, pracą, rozwojem zawodowym, życiem kulturalnym i społecznym - a tym samym stworzenie ośrodkom naukowym, placówkom i instytucjom opiekuńczym w Polsce i za granicą możliwości współpracy interdyscyplinarnej.

VII Międzynarodowy Kongres Inkluzji Społecznej, ze względu na pandemię panującą na całym świecie, odbył się online, tym razem pod hasłem „Inkluzja społeczna seniorów”. Program konferencji przewidywał dwie sesje plenarne oraz dwa panele dyskusyjne, które dotyczyły następujących obszarów tematycznych:

1. Wykluczenie społeczne seniorów - etiologia, fenomenologia i sposoby zapobiegania.

2. Współczesne problemy opieki senioralnej - przekonania, uprzedzenia i stereotypy postrzegania seniorów. 
3. Ageizm we współczesnym świecie - Uniwersytety Trzeciego Wieku, projekty i inne działania społeczne wobec osób starszych.

4. Bezpieczeństwo seniorów.

5. Projektowanie uniwersalne w opiece i aktywizacji senioralnej.

W obradach wzięli udział przedstawiciele następujących ośrodków naukowych z Polski:

- Uniwersytetu Warszawskiego,

- Uniwersytetu im. Adama Mickiewicza w Poznaniu,

- Uniwersytetu Jana Kochanowskiego w Kielcach,

- Akademii Pedagogiki Specjalnej im. Marii Grzegorzewskiej w Warszawie,

- Akademii Marynarki Wojennej im. Bohaterów Westerplatte w Gdyni,

- Uniwersytetu Marii Curie-Skłodowskiej w Lublinie,

- Uniwersytetu Przyrodniczo-Humanistycznego w Siedlcach,

Z gości zagranicznych zaszczycili nas swoją obecnością przedstawiciele:

- Uniwersytetu Sofijskiego im. św. Klemensa z Ochrydy (Bułgaria),

- Uniwersytetu Płowdiwskiego im. Paisjusza Chilendarskiego (Bułgaria),

- Uniwersytetu Medycznego w Warnie im. Paraskewa Stojanowa (Bułgaria),

- Instytutu Psychologii Rosyjskiej Akademii Kształcenia w Moskwie,

- Państwowego Uniwersytetu Pedagogicznego im. Lwa Tołstoja w Tule (Rosja),

- Petersburskiego Uniwersytetu Państwowego (Rosja),

- Państwowego Uniwersytetu w Omsku (Rosja),

- Państwowego Uniwersytetu im. P. Demidowa w Jarosławiu (Rosja),

- Białoruskiego Państwowego Uniwersytetu Pedagogicznego im. Maksima Tanka (Biaroruś).

Podczas trwania obrad rozpatrywano wiele aspektów zjawisk towarzyszących starości, uwzględniając jej różne konteksty: filozoficzny, społeczny, edukacyjny, wiktymologiczny, ekonomiczny (odnoszący się do wykorzystywania nowych technologii przez osoby starsze) i związany z bezpieczeństwem osób starszych. Prelegenci podnosili również pro- 
blem wizerunku osób starszych w oczach dzieci i młodzieży i związane z tym zagadnienie szacunku wobec osób starszych.

Niezwykle interesujące głosy naukowców i praktyków odnosiły się do kwestii związanych z edukacją młodzieży w zakresie opieki i komunikacji z osobami starszymi. Na Kongresie nie mogło zabraknąć głosu praktyków, przybliżającego sytuację osób starszych przebywających w instytucjach i ośrodkach zamkniętych. Zwrócono uwagę na istotną kwestię wolontariatu jako formy wsparcia osób starszych. Omawiano także obszary aktywizacji zawodowej seniorów.

W tematykę obrad doskonale wpisała się wystawa prac studentów UPH „Przemijanie...”, poprzedzona wystąpieniem Kierownika Pracowni Sztuki Uniwersytetu Przyrodniczo-Humanistycznego w Siedlcach, profesora Tomasza Nowaka.

\section{Substantive Report of the 7th International Congress of Social Inclusion}

Siedlce University of Natural Sciences and Humanities organizes the International Congress of Social Inclusion since 2014. The aim of the Congress is to gather around the academic community of the University scientists, experts, and practitioners dealing with various aspects of social inclusion issues - including education, work and professional development, cultural and social life and to create the possibility of interdisciplinary and international cooperation between research centers, institutions operating in the field of social care and inclusion.

This year's Congress, due to the pandemic situation around the world, was held online under the banner of Social Inclusion of Seniors. The conference programme included two plenary sessions and two discussion panels on the following thematic areas:

1. Social exclusion of seniors - etiology, phenomenology, and methods of prevention.

2. Modern problems of senior care - beliefs, prejudices, and stereotypes of the perception of seniors.

3. Ageism in the modern world - Universities of the Third Age, projects and other social activities towards the elderly. 


\section{Safety of seniors.}

5. Universal design in senior care and activation.

The deliberations were attended by representatives of Polish and abroad, including:

- University of Warsaw,

- Adam Mickiewicz University in Poznan,

- Jan Kochanowski University in Kielce,

- Academy of Special Pedagogy in Warsaw,

- Polish Naval Academy in Gdynia,

- Maria Curie-Skłodowska University in Lublin.

- Siedlce University of Natural Sciences and Humanities.

Among foreign guests, we were honored by our presence of representatives:

- Sofia University of Klimt Ohridski (Bulgaria),

- University of Plovdiv (Bulgaria),

- Medical University of Varna (Bulgaria),

- Psychological Institute of the Russian Academy of Education in Moscow (Russia),

- University of Tula (Russia),

- State University of St. Petersburg (Russia),

- State University of Omsk (Russia),

- University of Yaroslavl (Russia),

- State Pedagogical University in Minsk (Belarus).

Many aspects of old age were considered during the deliberations, the philosophical, social, educational, victimological, economic, and new technologies in the lives of the elderly and the safety of the elderly were discussed. Speakers also raised issues of the image of the elderly in the opinion of children and young people respect for the elderly.

An extremely interesting voice from scientists and practitioners referred to the education of young people in the context of culture, care, and communication with the elderly. 
There was no shortage of voices from practitioners in Congress regarding the care and care of the elderly in institutions and closed centres, and attention was drawn to the important issues of volunteering for the elderly. The areas of professional activation of seniorcitizens were also discussed.

The exhibition of the works of Siedlce University students "Passing...", preceded by a speech by the Head of the Art Studio of the University, professor Tomasz Nowak, perfectly matched the subject of the meeting. 